\title{
IMPLEMENTASI KEPEMIMPINAN KEPALA SEKOLAH BERDASARKAN MODEL KEPEMIMPINAN ISLAM BERBASIS KEARIFAN LOKAL DI LEMBAGA PENDIDIKAN AGAMA
}

\author{
Redmon Windu Gumati \\ STIT At-Taqwa Ciparay Kabupaten Bandung
}

INFO ARTIKEL

Diterima: 9-7-2021

Disetujui: 3-9-2021

\begin{abstract}
Abstrak: Penelitian ini dilatarbelakangi permasalahan munculnya tipe dan sifat kepemimpinan yang ideal, pemimpin yang selaras dengan nilai-nilai islami, dan memahami budaya lokal (local wisdom). Tujuan penelitian adalah untuk mengetahui implementasi kepemimpinan kepala sekolah berdasarkan model kepemimpinan islam berbasis kearifan lokal di lembaga pendidikan agama. Metode penelitian yang digunakan adalah metode penelitian studi kasus (case study), yaitu metode penelitian untuk memberikan batasan yang lebih bersifat teknis dengan penekanan pada ciriciri penelitiannya. Para peneliti berusaha menemukan semua variabel yang penting, yang pada hakikatnya ketika objek yang dikaji merupakan sistem yang semakin unik, spesifik, dan khusus, maka semakin besar manfaatnya. Setelah dilakukan penelitian, maka diperoleh hasil bahwa peran (role) seorang Kepala Sekolah sangat sentral dan strategis karena ia dibutuhkan sebagai motivator, mediator, dan komunikator di lembaga pendidikan agama.
\end{abstract}

\section{Kata Kunci:}

Kepemimpinan, Islam

dan Budaya Lokal.

\begin{abstract}
This research is motivated by the problem of the emergence of the type and nature of ideal leadership, leaders who are in harmony with Islamic values, and understanding local culture (local wisdom). The purpose of the study was to determine the implementation of principals' leadership based on Islamic leadership models based on local wisdom in religious education institutions. The research method used is a case study research method, namely a research method to provide a more technical limitation with an emphasis on the characteristics of the research. Researchers try to find all the important variables, which in essence when the object under study is a system that is more unique, specific, and special, the greater the benefits. After doing the research, it was found that the role of a school principal is very central and strategic because he is needed as a motivator, mediator, and communicator in religious education institutions.
\end{abstract}

\footnotetext{
Nama : : Redmon Windu Gumati

Institusi : : STIT At-Taqwa Ciparay Kabupaten Bandung

Surel : redmon.windu@gmail.com
}

Keberadaan sekolah yang dikelola oleh lembaga keagamaan memiliki pengaruh besar dalam dunia pendidikan, terutama di kota besar. Khasanah pengetahuan agama menjadi tren kembali pada masa modern untuk mendidik anak-anak yang mengarahkan pada keagamaan dan moral. Kepemimpinan sekolah menambah daya kemampuan pengelolaan sekolah untuk menjadi sekolah yang bertumpu pada eksistensi lembaga sekolah keagaamaan. Pengaruh besar tersebut mendorong tindakan orang tua wali untuk tergerak menyekolahkan anak-anaknya ke sekolah yang berbasis agama daripada sekolah umum di kota mereka. Orang tua wali berasumsi menyekolahkan anak-anak mereka di tempat berpengetahuan agama mempunyai nilai lebih di bidang agama dan berperilaku sesuai moral di dalam masyarakat. Penilaian orang tua wali berlatar belakang agama lebih baik menyekolahkan anaknya ke sekolah agama ataupun ke lembaga pendidikan keagamaan daripada ke sekolah umum sering kali di jumpai di kehidupan sosial. Selain itu, penilaian yang sama dari latar belakang kenyakinan dasar yang kuat lebih baik menempatkan cucunya ke dalam asrama di bandingkan dengan sekolah swasta yang berpandangan umum. Mereka cenderung menempatkan anak cucunya ke sekolah yang 
membelajarkan dasar-dasar agama agar kenyakinan generasinya semakin kuat. Latar belakang keluarga atau kenyakinan keluarga menjadi dasar penentuan peminat sekolah untuk menjadi jembatan masa depan anak-anak mereka.

Peran kepala sekolah sebagai pemimpin (leader) perannya sangat penting untuk membantu guru dan muridnya. Kepemimpinan kepala sekolah harus dapat memahami, mengatasi dan memperbaiki kekursangan-kekurangan yang terjadi di lingkungan sekolah. Untuk meningkatkan kualitas pendidikan seorang kepala sekolah harus mampu meningkatkan kinerja para guru atau bawahannya. Banyak faktor yang dapat mempengaruhi kinerja seseorang, sebagai pemimpin sekolah harus mampu memberikan pengaruh-pengaruh yang dapat menyebabkan guru tergerak untuk melaksanakan tugasnya secara efektif sehingga kinerja mereka akan lebih baik, terutama pengaruh moral keagamaan untuk menjadi contoh kepada bawahannya. Rohmat (2010: 12) menyatakan kepemimpinan pendidikan menjadi sistem mekanisme yang harus melibatkan semua unsur dalam pendidikan, yaitu terkait manajemen pendidikan dan administrasi pendidikan. Dalam hal ini Maxwell (2002: 32) berpendapat bahwa kepemimpinan adalah pengaruh tidak lebih yakni kemampuan memperoleh pengikut.

Suryaman (2010: 16) mengungkapkan bahwa peran kepala sekolah sebagai pimpinan tertinggi dalam sebuah lembaga pendidikan sangat besar dalam pengembangan pendidikan berbasis multikultural di sekolah. Dengan kepemimpinan berbasis multikultural, proses pelaksanaan PBM (Proses Belajar-Mengajar) lebih baik, dan mampu meredam konflik-konflik internal dan eksternal. Gistituati (2005: 76) mengungkapkan bahwa kebutuhan akan pendidikan yang berkualitas adalah sangat esensial bagi suatu bangsa atau daerah tersebut. Oleh Karena itu, peningkatan kualitas pendidikan harus menjadi perhatian penting. Agar kualitas pendidikan kita bisa meningkat, diperlukan perubahan paradigma dari Pemda, pengawas, kepala sekolah, guru, murid, orang tua dan masyarakat tentang penyelengaraan pendidikan. Penjelasan tentang karakter nilai-nilai keagamaan kepemimpinan sekolah yang berbasis keagamaan di lembaga pendidikan sekolah menegah atas surabaya dan sebagai sarana untuk memberikan diskripsi kepada dunia akademik dan kalangan publik. Sebagai penjelasan fenomena kepemimpinan di dalam kegiatan koordinasi kepemimpinan untuk proses belajar mengajar bagi peningkatan profesionalitas guru untuk pengajaran masalah sosial pada fenomena-fenomena dalam masyarakat. Landasan pendidikan menjelaskan pengembangan mata pelajaran dan pendidikan disiplin ilmu dalam pengembangan, baik pengembangan struktur, metodologi, dan pemanfaatan pendidikan sebagai pendidikan disiplin ilmu. Kepemimpinan kepala sekolah pada sekolah agama ini mengembangkan landasan pendidikan pada landasan religiusitas yang di terapkan Indonesia dalam menghendaki adanya keseimbangan antara materi yang bersumber dari intraceptive knowlegde dan extraceptive knowledge. Dasarnya landasan religius memberikan sistem gagasan-gagasan mendasar tentang nilai-nilai, norma, etika, dan moral. Inilah kepemimpinan kepala sekolah berbasis keagamaan dalam nilai-nilai religius kepemimpinan kepala sekolah di lembaga pendidikan agama yang di dasarkan pada latar belakang pemimpin dan bentuk-bentuk perilaku yang mendasar sebagai seorang pemimpin pada pelaksanaan struktur organisasi dari fenomena merebaknya berbagai sekolah yang tumbuh berlandaskan keagamaan, dipandang dari perspektif Emile Durkheim mengenai kepercayaan, disebutkan sebagai bentuk-bentuk perilaku ritualisme.

\section{METODE}

Metode penelitian studi kasus (case study) yang digunakan dalam penelitian ini yang menurut Smith (dalam Denzin, 2009: 23), kasus adalah suatu "kasus yang terbatas", maksudnya dalam ilmu-ilmu sosial dan layanan kemanusiaan, kasus memiliki bagian operasional, bisa jadi bertujuan dan bahkan memiliki jiwa. menurut Yin (1987: 98) studi kasus memberikan batasan yang lebih bersifat teknis dengan penekanan pada ciri-cirinya. Para peneliti berusaha menemukan semua variabel yang penting. Pada hakikatnya ketika objek yang dikaji merupakan sistem yang semakin unik, spesifik, dan khusus, maka semakin besar manfaatnya. Menurut Stake (dalam Denzin, 2009: 56) untuk sementara seorang peneliti mengabaikan rasa 
keingintahuannya yang lain agar kasusnya dapat memunculkan kisah yang uniknya sendiri. Akan tetapi tujuan jenis kasus ini bukan untuk memahami konstruk abstrak atau fenomena umum tertentu dan bukan untuk merumuskan suatu teori yang bisa jadi pada saat yang lain seorang peneliti justru melakukan hal ini. Stake (2005: 132) selalu menekankan tentang pentingnya untuk selalu mengeksplorasi dan menjelaskan hal-hal penting yang khas yang terdapat di dalam kasus, karena pada dasarnya kasus dipilih karena diperkirakan mengandung kekhususannya sendiri. Subjek penelitian adalah Kepala Sekolah di Lembaga Pendidikan Agama, maka teknik pengumpulan data dalam penelitian ini menggunakan observasi terlebih dahulu untuk mengetahui sumber data. Teknik wawancara digunakan untuk menggali data dalam penelitian ini ialah dengan wawancara mendalam. Teknik pemeriksaan keabsahan data atau tujuan triangulasi ini memanfaatkan sesuatu yang lain dalam membandingkan hasil wawancara terhadap objek penelitian dalam kepemimpinan sekolah dalam lembaga pendidikan yang dikelola sekolah keagamaan. Denzin (2009) mendefinisikan triangulasi sebagai gabungan atau kombinasi berbagai metode yang dipakai untuk mengkaji fenomena yang saling terkait dari sudut pandang dan perspektif yang berbeda. Tahapan triangulasi pada penelitian kepemimpinan di sekolah keagamaan ini mencakup: triangulasi metode, triangulasi sumber, dan triangulasi teori. Menurut Flick (dalam Denzin: 2009) teknik triangulasi dapat digunakan untuk mengklarifikasi makna dengan cara mengidentifikasikan cara pandang yang berbeda terhadap berbagai fenomena. Alternatif interpretasi dengan pengkategorisasikan dibutuhkan untuk menentukan interpretasi yang sesuai dengan kondisi dan keadaan kasus dengan maksud dan tujuan penelitian. Setiap interpretasi kategorisasi dapat menggambarkan makna-makna yang terdapat di dalam kasus, yang jika diintegrasikan dapat menggambarkan keseluruhan Penelitian.

\section{HASIL}

Kepemimpinan sekolah berbasis agama memberikan pengaruh besar dalam dunia pendidikan. Kepercayaan elementer menjadi dasar dimana sekolah mencipta. Anggapan amanah terhadap kepemimpinan sekolah terdapat suatu indikasi ideologi pendidikan konservatif dan liberal di beberapa keragaman sekolah. Amanah disampaikan beberapa pemimpin sebagai sebuah tanggung jawab. Tanggungjawab ini dilaksanakan untuk dapat mengembangkan tugastugas dan rencana kerja yang diberikan selama pemimpin itu menjabat sebagai kepala sekolah. Amanah-amanah kepala sekolah ini sebagian besar di dapatkan oleh pemimpin atasan yang berhak memberikan jabatan bagi dirinya, sesuai dengan tingkatan kemampuan yang dimiliki.

Persamaan pendapat tanggungjawab mengenai pelaksanaan amanah dilakukan oleh kepala sekolah keagamaan ini telah diberikan dari kepercayaan atasan melalui kemampuan yang dimilikinya. Amanah ini dipercayakan kepada pemimpin yang di anggap mampu untuk dapat mengembangkan institusi pendidikan yang nantinya seorang kepala sekolah memimpin. Suatu amanah dipercayakan untuk dapat mengembangkan kepemimpinan nantinya akan terus mereka pertahankan agar kepercayaan atasan dapat mereka miliki. Kepemimpinan menekankan adanya amanah dari tanggungjawab dari jabatan sebagai kepala sekolah yang menekankan peran sentral pelatihan kerohanian sebagai landasan pembangunan karakter moral yang tepat di dalam konvervatisme pendidikan secara religius. Lebih lanjut kepemimpinan memusatkan pada perhatian perlunya melestarikan dan meneruskan kenyakinan-kenyakinan dan praktik-praktik yang sudah ada, sebagai cara untuk menjamin pertahanan kehidupan secara sosial serta efektivitas secara kuat oleh orientasi pendidikan yang bersifat mendakwahkan agama.

Pemimpin sekolah agama memperjuangkan pengaruhnya di depan guru dan karyawan tidak semata-mata demi kondisi yang dihadapi akan tetapi ada tujuan yang ingin pemimpin itu raih. Tujuan yang ingin di capai oleh seorang pemimpin agama adalah ridho dari Tuhan. Ridho merupakan dambaan setiap muslim yang menyadari bahwa itulah harta termahal yang pantas diperebutkan oleh manusia. Tanpa ridho, hidup akan hampa, kering, tidak dapat merasakan nikmat atas segala apa yang telah ada di genggaman, dengan bermacam masalah silih berganti menyertai hidup.

Kekuatan jiwa diciptakan pemimpin religius untuk menunjukkan sandaran keimanan dalam kepemimpinannya melaksanakan tanggungjawab mengembangkan lembaga pendidikan. Standar keimanan seseorang terletak pada akidah yang dimilikinya. Akidah pemimpin terletak pada 
KARANGAN: Jurnal Kependidikan, Pembelajaran, dan Pengembangan, Vol 03 No 02, Bulan September, Tahun 2021 Hal 87-96

kenyakinan diri kepada Tuhan dan menyakini berbagai sifat-sifat Tuhan. Sifat-sifat Tuhan inilah yang layak di pahami untuk menjadi panduan kita dalam mengembangkan potensi standar keimanan pemimpin dalam menghadapi kesulitan hidup.

Pemimpin agama dalam proses kepemimpinannya tidak terlepas dari sosok pemimpin teladan yang menjadi tokoh panutannya yang memberikan inspirasi dalam setiap pelaksanaan kepemimpinan di dalam sekolah yang berbasis agama. Murid memiliki ikatan emosional keagamaan yang kuat dengan sosok guru. Perasaan kepemilikan pribadi oleh kepala sekolah dalam yayasan adalah landasan berpikir feodalistik. Hal ini membuat hubungan antara peserta didik dan pendidik, pendidik dan pemilik yayasan dikaikan pada hubungan patron klien dari munculnya paradigma pendidikan yang anti perubahan dan keadilan.

Cobaan hidup berupa keburukan dan kesulitan lebih mudah dipahami, semisal mengalami sakit, hilang harta benda, kesulitan dan kesempitan hidup, kondisi demikian biasanya manusia akan segera berdoa dan mengharapkan pertolongan dari Tuhan. Cobaan datang untuk menunjukkan hikmah yang nantinya didapatkan untuk manusia termasuk seorang pemimpin di sekolah agama yang mendapatkan tanggungjawab memimpim sekolah dan menyelesaikan tugas-tugasnya demi perkembangan sekolah dan anak didiknya.

Proses penyampaian ilmu atau dakwah dapat diartikan sebagai proses pembelajaran di lingkungan sekolah untuk memberikan bahan ajar kepada murid. Kepala Sekolah melakukan dakwah melalui pendidikan. Esensi dakwah adalah menyebarkan agama islam kepada orang lain. Dakwah yang dilakukan beliau kepada anak-anak dengan menggunakan manajemen hati. Manajemen hati ini yang kadangkala dapat menyadarkan anak-anak untuk dapat menyadari kesalahan yang telah mereka perbuat dalam kehidupan sehari-hari mereka. Kegiatan apel pagi sebelum belajar merupakan bentuk ritual yang bertujuan untuk melatih kedisiplinan siswa. Tahfidz Qur'an merupakan salah satu sarana memelihara amal. Antara Al Qur'an dan amal shalih mempunyai hubungan berimplikasi (jika dan hanya jika). Berinteraksi dengan Al Qur'an mendorong kita beramal shalih dengan beramal shalih kita mudah berinteraksi dengan Al Qur'an. Kegiatan apel pagi sebelum belajar merupakan bentuk ritual yang bertujuan untuk melatih kedisiplinan siswa di. Tahfidz Qur'an merupakan salah satu sarana memelihara amal. Antara Al Qur'an dan amal shalih mempunyai hubungan berimplikasi. Berinteraksi dengan Al Qur'an mendorong kita beramal shalih dengan beramal shalih kita mudah berinteraksi dengan Al Qur'an. Termasuk kegiatan sholat berjama'ah.

Lingkungan agamis mempengaruhi proses belajar mengajar untuk siswa di dalam lingkungan belajar yang religius di kepemimpinan sekolah berbasis agama. Kondisi pada lingkungan yang mengedepankan hal-hal yang religius menjadikan proses akademik di tambah nilai-nilai keagamaan menjadi nilai plus untuk siswa. Sistem kemimpinan sekolah di sekolah agama ini membuktikan bahwa sekolah agama menyodorkan nilai tambah bagi proses belajar.

Penilaian terhadap etos kerja masih belum mempunyai sistem. Sistem yang dimaksud adalah penghargaan terhadap etos kerja terhadap nilai-nilai keadilan. Adanya sistem seperti itu di sekolah tersebut, dimisalkan mengikuti perlatihan workshop untuk meningkatkan sistem metode kerja guru. Peraturan etos kerja guru dilaksanakan tanpa paksaan dengan mengadakan sistem hukuman dan penghargaan kepada pihak-pihak sekolah yang disepakati dan disosialisasikan agar semua pihak sekolah mengetahui sistem aturan tersebut. Memimpin sekolah dengan sistem manajerial dengan didasari oleh semangat spiritualnya. Sistem manajerial yang dijalankan kepala sekolah ini mengikuti prosedur dari pemerintah, kantor pengelolaan dan tenaga pendiri atau yayasan tersebut. Kegiatan-kegiatan yang ada di sekolah ini semua didasari atas semangat spiritual. Beliau mengungkapkan melakukan pekerjaan dengan semangat spiritual ini maka pekerjaan yang diterimanya akan dilaksanakan dengan maksimal.

Kegiatan-kegiatan tersebut memberikan keluasan terhadap ideologi siswa dalam mencari pengetahuan sebagai alat untuk keperluan pemecahan masalah praktis di dalam pembelajaran sekolah tersebut. Hal ini memberikan gambaran sekolah agama mendukung konsep manusia yang rasional liberal dalam penentuan potensi sama dalam intelektual, memiliki norma sosial, dan otonom.

Ketika membahas kepemimpinan kita akan berbicara antara lain mengenai perihal pemimpin, konsep kepemimpinan, dan mekanisme pemilihan pemimpin. Sebelum 
membicarakan lebih jauh soal kepemimpinan, ada baiknya dilakukan peninjauan terlebih dahulu definisi konsep pemimpin. Pendefinisian ini dapat membantu kita untuk memahami dan melakukan pembahasan menurut alur yang sistematis.

Banyak definisi tentang pemimpin baik itu menurut ahli politik, ekonomi, sosial, antropologi (budaya) maupun agama. Saya hanya akan menyampaikan definisi yang relevan dengan pokok pembahasan. Seorang ahli sosiologi, Soerjono Soekanto, menghubungkan kepemimpinan (leadership) dengan kemampuan seseorang sebagai pemimpin (leader) untuk mempengaruhi orang lain (anggotanya), sehingga orang lain itu bertingkah laku sebagaimana dikehendaki oleh pemimpinannya (Soekanto, 1984: 60). Ahli sosiologi yang lain, Wahyusumijo, lebih melihat kepemimpinan sebagai suatu proses dalam mempengaruhi kegiatan-kegiatan seseorang atau sekelompok orang dalam usahanya mencapai tujuan yang sudah ditetapkan (Wahyusumijo, 1984: 60).

Di pihak lain, dalam antropologi budaya, muncul pandangan yang membedakan antara kepemimpinan sebagai suatu kedudukan sosial dan sebagai suatu proses sosial (Koentjaraningrat, 1969: 181). Kepemimpinan sebagai kedudukan sosial merupakan kompleks dari hak-hak dan kewajiban-kewajiban yang dapat dimiliki oleh seseorang atau suatu badan. Sementara sebagai suatu proses sosial, kepemimpinan meliputi segala tindakan yang dilakukan oleh seseorang atau suatu badan yang mendorong gerak warga masyarakat.

Apabila kepemimpinan diartikan sebagai kemampuan seseorang untuk mempengaruhi orang lain sehingga mereka mengikuti kehendaknya, maka seseorang itu dapat disebut mempunyai pengaruh terhadap oarang lain. Pengaruh itu dinamakan kekuasaan atau wewenang. Istilah kekuasaan dalam hal ini merujuk pada kemampuan seseorang untuk mempengaruhi orang atau pihak lain, sedangkan wewenang merupakan kekuasaan seseorang atau sekelompok orang yang mendapat dukungan atau pengakuan dari masyarakat. Dalam hubungan dengan kepemimpinan, Kartini Kartono (1982: 78) mengatakan bahwa kepemimpinan harus dikaitkan dengan tiga hal penting yaitu kekuasaan, kewibawaan, dan kemampuan.

Sementara itu dilihat dari sudut pandang agama (Islam), istilah kepemimpinan berasal dari kata 'pemimpin', artinya orang yang berada di depan dan memiliki pengikut, terlepas dari persoalan apakah orang yang menjadi pemimpin itu menyesatkan atau tidak. Dalam konteks Islam, setidaknya ada dua konsep penting yang berkaitan dengan kepemimpinan, yaitu imamah dan khilafah. Masing-masing kelompok Islam memiliki pendefinisian berbeda tentang kedua konsep itu, meskipun ada juga yang menyamakannya.

Kaum Sunni menyamakan pengertian khilafah dan imamah. Dengan perkataan lain, imamah disebut juga sebagai khilafah. Bagi kaum Sunni, orang yang menjadi khilafah adalah penguasa tertinggi yang menggantikan Rasulullah SAW. Oleh karena itu khilafah juga disebut sebagai imam (pemimpin) yang wajib ditaati (As-Salus, 1997: 16). Sebaliknya, kaum Syiah membedakan pengertian khilafah dan imamah. Hal ini dapat dilihat dalam sejarah kepemimpinan Islam setelah Rasulullah SAW wafat. Kaum Syiah bersepakat bahwa pengertian imam dan khilafah itu sama ketika Ali bin Abi Thalib diangkat menjadi pemimpin. Namun sebelum Ali bin Abu Thalib menjadi pemimpin, mereka membedakan pengertian antara imam dan khilafah. Abu Bakar, Umar bin Khattab, dan Ustman adalah khalifah namun mereka bukanlah imam (Amini, 2005: 18). Dalam pandangan kaum Syiah, sikap seorang imam haruslah mulia sehingga menjadi panutan para pengikutnya. Imamah didefinisikan sebagai kepemimpinan masyarakat umum, yakni seseorang yang mengurus persoalan agama dan dunia sebagai wakil dari Rasulullah SAW. Rasulullah SAW yang menjaga agama dan kemuliaan umat wajib dipatuhi dan diikuti. Imam mengandung makna lebih sakral daripada khalifah. Secara implisit kaum Syiah menganut pandangan bahwa khalifah hanya mencakup ranah jabatan politik, tidak melingkupi ranah spiritual-keagamaan; sedangkan imamah meliputi seluruh ranah kehidupan manusia baik itu agama maupun politik.

Seperti halnya kaum Sunni dan Syiah, kalangan Islam sekular memiliki pandangan sendiri tentang kepemimpinan. Konsep kepemimpinan kelompok Islam sekular dalam hal ini cenderung mengacu pada kepemimpinan model Barat. Meskipun kelompok Sunni, Syiah, dan Islam sekular mempunyai sudut pandang yang berbeda mengenai kepemimpinan, ketiganya menunjukkan 
KARANGAN: Jurnal Kependidikan, Pembelajaran, dan Pengembangan, Vol 03 No 02, Bulan September, Tahun 2021 Hal 87-96

kesepahaman bahwa suatu masyarakat haruslah memiliki seseorang pemimpin. Setiap masyarakat dengan demikian tidak mungkin dapat dipisahkan dari masalah kepemimpinan.

\section{Model Kepemimpinan Berbasis Kearifan lokal}

Pemimpin yang terpilih harus mendapatkan legitimasi dari anggotanya atau warga masyarakat yang dipimpinnya. Seorang pemimpin dapat memiliki wewenang untuk memimpin secara resmi setelah mendapat legitimasi berdasarkan pada prosedur yang telah ditetapkan dalam adat-istiadat atau hukum yang berlaku dalam masyarakat yang bersangkutan. Prosedur itu tentu saja dapat berbeda baik antara masyarakat yang satu dan yang lain maupun dari waktu ke waktu.

Dalam masyarakat tradisional, misalnya, legitimasi atas kepemimpinan seseorang pada umumnya dilakukan melalui rangkaian upacara yang melibatkan kehadiran roh nenek moyang atau dewa-dewa. Pada zaman kerajaan, prosedur untuk melegitimasi kepemimpinan seseorang dapat dilakukan melalui pemilihan, pemilihan bertingkat atau pemilihan oleh sebagian masyarakat. Wahyu, nurbuat, pulung, ngalamat, dan mimpi juga merupakan unsur-unsur yang berperan penting baik dalam pemilihan pemimpin maupun legitimasi atas kepemimpinannya (Kartodirdjo, 1973: 8).

Oleh karena itu, untuk mendapatkan kekuasaan dalam kepemimpinan, seseorang harus menempuh berbagai jalan (laku) yang panjang. Kekuasaan dapat juga diperoleh melalui keturunan atau lewat kekuatan fisik. Pada zaman modern ini, kepemimpinan dapat pula diperoleh melalui pendidikan dan pemilihan berdasarkan keahlian atau spesialisasi. Untuk menduduki jabatan pada berbagai level tidak lagi didasarkan terutama pada keturunan, melainkan pada tingkat pendidikan formal (Sutherland, 1983: 12).

Calon pemimpin yang berhasil terpilih harus mendapatkan pengakuan dari masyarakat. Masyarakat Indonesia, terutama yang berada di daerah pedesaan, masih mempercayai bahwa seorang pemimpin mempunyai wibawa, wewenang, kharisma, dan kekayaan. Persyaratan ini penting bagi para pemimpin di tingkat kota atau pedesaan, sebab mereka pada masa sekarang atau zaman demokrasi dipilih secara langsung oleh rakyat.

Kaidah dasar kehidupan masyarakat Jawa lebih mengutamakan prinsip kerukunan dan sikap hormat kepada alam, pencipta, leluhur, guru, orang tua, bangsa, negara, dan agama (Magnis-Suseno, 1985: 36-38). Orang Jawa umumnya juga mengutamakan keselarasan dalam hidup bermasyarakat (Mulder, 1981: 17). Pandangan hidup dan pola pikir yang demikian sudah barang tentu sangat mempengaruhi masyarakat Jawa dalam meletakkan dasar-dasar kemasyarakatan dan kebudayaan. Apabila hal ini dihubungkan dengan masalah kepemimpinan, maka seorang pemimpin sedapat mungkin harus mampu memperlihatkan sikap hidup yang sederhana, jujur, adil, bertenggang rasa (tepa selira), hemat, disiplin, dan taat kepada hukum (Koentjaraningrat, 1981: 64).

Berbagai piwulang dan pitutur telah mengajarkan tentang sifat-sifat seorang pemimpin. Dalam ajaran Ki Hajar Dewantara sebagai tokoh pendidikan, misalnya, dinyatakan bahwa seorang pemimpin harus mempunyai tiga pilar, yaitu: "Ing Ngarso Sung Tuladha, Ing Madya Mangun Karsa, Tut Wuri Handayani". Demikian pula dalam kakawin Ramayana dan Mahabarata, dinyatakan bahwa seorang pemimpin harus memperlihatkan sikap yang merujuk pada ajaran tentang Hasta Bhrata, yaitu mencontoh sikap delapan dewa, di antaranya Dewa Surya, Candra, Bayu, dan Baruna Dewa Air yang antara lain mempunyai sifat sabar. Dalam filsafat Jawa pun terdapat banyak istilah tentang sifat-sifat pemimpin yang yang dikenal dengan "empat t", yaitu teteg-sebagai pengayom, tatag-berani, tangguh-kuat, dan tanggon-pantang mundur, mrantasi sabarang karya (gawe).

Dalam era pascamoderen yang mengagungkan multikulturalisme sebagai pandangan hidup, etika kedaifan identik dengan menghargai orang lain (liyan) atau menganggap diri sebagai sosok yang lemah dan membutuhkan keberadaan orang lain dalam menjalani kehidupan bersama yang semakin berat. Kehidupan dalam etika kedaifan, menurut Goenawan Muhammad sebagaimana disitir oleh Triyanto Tiwikromo, sama halnya dengan tidak menganggap orang lain seperti yang dikatakan oleh Sartre yaitu sebagai neraka. Semangat multikulturalisme dan demokrasi menempatkan rakyat sebagai sahabat, kanca, untuk mencapai masyarakat yang aman dan sejahtera (Tiiwikromo, 2008: 4) 
KARANGAN: Jurnal Kependidikan, Pembelajaran, dan Pengembangan, Vol 03 No 02, Bulan September, Tahun 2021 Hal 87-96

\section{Model Kepemimpinan Islam}

Dalam pandangan Islam, seorang pemimpin harus mempunyai kualitas spiritual, terbebas dari segala dosa, memiliki kemampuan sesuai dengan realitas, tidak terjebak pada dan menjauhi kenikmatan dunia, dan harus memiliki sifat adil. Adil dalam hal ini dapat dipahami sebagai cara menempatkan sesuatu pada tempatnya yang layak. Penerapan sifat keadilan oleh seorang pemimpin dapat dilihat dari bagaimana caranya mendistribusikan sumberdaya politik, ekonomi, sosial, dan budaya kepada rakyatnya.

Melihat kemajemukan masyarakat Indonesia, maka tantangannya adalah bagaimana cara mengembangkan pluralisme dalam konteks membangun kepemimpinan dan kedaulatan bangsa. Fungsi kepemimpinan adalah sebagai ulil amri dan khadimul ummah, artinya amanah jabatan dan kekuasaan harus digunakan sesuai dengan tuntutan Allah dan Rasul-Nya, berlaku adil, dan melindungi kepentingan masyarakat.

Dengan demikian, meskipun Islam adalah agama mayoritas, jangan sampai kepentingan umat Islam mengakibatkan negara lebih banyak melayani kepentingan segelintir orang yang mengusai aparatur negara. Sementara mereka yang berusaha menyuarakan ide-ide demokrasi, pluralisme, dan perlindungan hak-hak asasi manusia cenderung dituding tidak memiliki nasionalisme.

Menurut Abdurrahaman Wahid (1988: 51), terdapat lima jaminan dasar dalam menampilkan universalisme Islam, baik pada perorangan atau kelompok. Kelima jaminan dasar yang dimaksud meliputi keselamatan fisik masyarakat dan tindakan badani di luar ketentuan hukum, keselamatan keluarga dan keturunan, keselamatan harta benda dan milik pribadi di luar prosedur hukum, dan keselamatan profesi. Dalam pandangan Abdurahman Wahid, kelima jaminan dasar umat manusia akan sulit diwujudkan tanpa adanya kosmopolitanisme peradaban Islam. Kosmopolitanisme peradaban Islam harus menghilangkan batasan etnis, pluralisme budaya, dan heterogenitas politik. Hal ini akan tercapai apabila terjadi keseimbangan antara kecenderungan normatif kaum muslimin dan kebebasan berpikir semua masyarakat termasuk kalangan nonmuslim. Oleh karena itu, rahmatan lil alamin harus dibuktikan dalam wujud kehidupan bermasyarakat dan berbangsa serta bernegara. Di samping itu, kosmopolitanisme Islam mengacu pada modernisasi religiusitas, artinya harus berlandaskan pada keagamaan dan pembebasan masyarakat untuk melakukan amar ma'ruf nahi mungkar. Hal ini berartik bahwa konsistensi terhadap demokrasi dan hak asasi manusia mutlak diperlukan. Lebih lanjut dinyatakan bahwa dalam universalisme Islam terdapat beberapa hal yaitu toleransi, keterbukaan sikap, kepedulian terhadap unsur-unsur utama kemanusiaan, dan perhatian dengan kearifan akan keterbelakangan dan kebodohan serta kemiskinan (Wahid, 1988: 77).

Universalisme Islam juga berarti kesalehan sosial (Munir, 2005: 21). Meskipun demikian, dalam konteks yang demikian bukan berarti bahwa negara Islam maupun kepemimpinan Islam adalah yang ideal. Universalisme Islam dan pluralisme lebih tepat dipahami sebagai ruh dalam konteks membangun kepemimpinan nasional. Bagi bangsa Indonesia, syariat tidak harus menjadi fondamen dan jiwa dari agama dan negara. Perlu diperhatikan pula bahwa multikulturalitas bangsa Indonesia dapat bermakna ganda, ibarat dua sisi mata pedang. Di situ sisi multikulturalitas itu merupakan modal sosial yang dapat menghasilkan energi positif dan memperkaya kultur bangsa, namun di sisi sebaliknya juga dapat menjadi energi negatif berupa ledakan destruktif yang setiap saat dapat menghancurkan struktur dan pilar-pilar bangsa. Masalah yang krusial adalah bagaimana cara mengatasi dan mencari solusi atas perpecahan yang terjadi akibat keanekaragaman itu tidak bisa dikelola dengan kebijakan politik yang demokratis dan egaliter termasuk di dalamnya pola-pola kepemimpinan. Apabila ditangani dengan baik, keanekaragaman itu justru merupakan aset dan kekayaan bangsa.

Oleh karenanya, penting dibangun hubungan intersubjektif yang mampu melahirkan keikhlasan yang didasarkan pada nilai-nilai kebenaran dan kejujuran. Keikhlasan merupakan peleburan ambisi pribadi ke dalam pelayaran kepentingan seluruh bangsa. Harus ada konsensus antarpemimpin dan ketundukan pada keputusan yang dirumuskan sang pemimpin. Untuk mencapai hal itu ada dua prasyarat yang harus dipenuhi, yaitu kejujuran sikap dan ucapan yang disertai dengan sikap mengalah untuk kepentingan bersama (Wahid, 2006: 57).

Pengembangan Sifat Pemimpin 
KARANGAN: Jurnal Kependidikan, Pembelajaran, dan Pengembangan, Vol 03 No 02, Bulan September, Tahun 2021 Hal 87-96

Sifat pemimpin harus dikembangkan sendiri karena sifat seseorang berbeda satu sama lain. Kepribadian ikut mempengaruhi sifat dan perilaku kepemimpinan seseorang. Pemimpin harus senantiasa meningkatkan kemampuan, mempraktikkan keterampilan, mencari peluang, dan mengembangkan potensi anak buah. Sebagai pedoman bagi pemimpin adalah "perlakukan orang lain sebagaimana Anda ingin diperlakukan". Dengan cara itu seorang pemimpin berusaha memandang suatu keadaan dari sudut pandang orang lain atau tenggang rasa.

Merujuk pada pendapat Geofrey G. Meredith, kualitas pemimpin dapat diukur dengan memperhatikan sejumlah hal berikut: (1) yakinkan bahwa dirinya seorang pemimpin, (2) banyak orang yang mencari bapak untuk minta dipimpin atau bertanya, (3) kembangkan dan terapkan ide-ide baru, (4) mainkan peranan aktif dalam kehidupan masyarakat, (5) tingkatkan kekuasaan dan hilangkan kelemahan, (6) tingkatkan program dan rencana tentang kepemimpinan, (7) belajarlah dari kesalahan terdahulu, (8) berorientasilah kepada hasil dan selesaikan sesuatu yang telah dimulai, (9) gunakan kekuatan sebagai pemimpin untuk membantu orang lain, (10) yakinkan orang lain tentang kemampuan, (11) dengarkan masukan, saran, dan nasihat atau kritik sekalipun, dan (12) lakukan perubahan ke arah kemajuan (Meredith, t.t.: 18-21).

Dalam membicarakan hubungan antara pemimpin dan rakyat dalam pembangunan, perlu dilihat berbagai variabel yang dapat dikelompokkan ke dalam independent variable dan dependent variable. Sebagai independent variable adalah bahwa seorang pemimpin seharusnya mempunyai dasar antara lain mengabdi pada kepentingan umum, memperhatikan rakyat baik di dalam maupun di luar pekerjaan, dan menciptakan komunikasi yang lancar dengan bawahan (rakyat). Dependent variable atau variabel yang dipengaruhi meliputi antara lain semangat kerja, displin kerja, gairah kerja, dan hubungan yang harmonis dengan bawahan. Kedua variabel ini akan mempengaruhi keberhasilan kepemimpinan seseorang dalam sebuah lembaga, baik itu di tingkat desa, kota ataupun pusat. Hubungan antara sejumlah variable yang telah disebutkan di atas dengan keberhasilan kepemimpinan dapat dilihat secara geometrik sebagai berikut.

Pendapat lain dikemukakan oleh Kartini Kartono (1982: 31), yang menyatakan bahwa keberhasilan pemimpinan berhubungan dengan pengelolaan kekuasaan, kewibawaan, dan kemampuan. Keberhasilan seorang pemimpin juga dapat ditentukan dari bentuk kerja sama dalam pembangunan yang tidak hanya untuk anggotanya, namun dari masyarakat untuk masyarakat (Syawani, 1978: iii). Pembangunan di sini dapat diartikan sebagai usaha atau rangkaian usaha pertumbuhan dan perubahan terencana yang dilakukan secara sadar oleh suatu bangsa, negara, dan pemerintah menuju modernitas dalam rangka pembinaan bangsa (Siagian, 1981: 99). Seorang pemimpin harus mempunyai kekuasaan yang bersumber pada hak milik kebendaan, kedudukan, kekuasaan, birokrasi, dan juga kemampuan khusus (supranatural) yang lain daripada orang biasa. Menurut Max Weber, kekuasaan itu cenderung pada kekuasaan yang kharismatik. Selain itu, seorang pemimpin biasanya juga mempunyai legitimasi berupa bendabenda pusaka dan sebagainya.

Masyarakat tidak dapat bergerak tanpa adanya pemimipin sebagai mediator dan motivator serta komunikator dalam pembangunan di berbagai bidang. Pemimpin harus dapat menjalankan ketiga fungsi itu dalam kelompoknya. Dalam struktur organisasi, peran seorang pemimpin tidak ada artinya tanpa dukungan rakyatnya. Hubungan antara pemimpin dan rakyat merupakan hal yang mutlak karena keduanya saling membutuhkan dan saling melengkapi. Hubungan yang demikian itu dapat digambarkan dengan menggunakan sebuah pepatah Jawa: kaya godhong suruh lumah lan kurebe yen disawang beda rupane, yen dimamah gineget padha rasane.

Hubungan antara pemimpin dan rakyat dapat pula digambarkan sebagai hubungan patroncilent (patronase), yaitu hubungan antara bapak dan anak. Bapak (pemimpin) berkewajiban melindungi anak-anaknya, sedangkan anak-anak harus patuh kepada bapaknya sebagai pemimpin (Koentjaraningrat, 1981: 191). Hubungan antara pemimpin dan anggotanya sering kali bertolak dari kebutuhan anggotanya (Legg, 1983: 21). Dalam kedudukan sosial, seorang pemimpin berperan mengontrol dan mengawasi serta menggerakkan segala aktivitas dalam masyarakatnya. Pemimpin yang baik akan dianggap oleh anggotanya sebagai cermin, guru, dan tokoh kunci (key person). 
KARANGAN: Jurnal Kependidikan, Pembelajaran, dan Pengembangan, Vol 03 No 02, Bulan September, Tahun 2021 Hal 87-96

\section{Simpulan}

Berdasarkan pembahasan di atas, maka dapat disimpulkan bahwa dalam setiap Lembaga Pendidikan Agama selalu dibutuhkan kehadiran sosok seorang pemimpin. Peran (role) seorang Kepala Sekolah sangat sentral dan strategis karena ia dibutuhkan sebagai motivator, mediator, dan komunikator dalam pendidikan. Sebagai seorang pemimpin, Kepala Sekolah dalam menjalankan kepemimpinannya harus mendapatkan legitimasi. Sikap kepemimpinan yang sesuai dengan model kepemimpinan dan sifat-sifat ideal dianggap mulia akan menjadikan seorang pemimpin sebagai idola bagi masyakat khusus, yaitu guru, murid, dan staf sekolah yang dipimpinannya. Ada beragam tipe atau model kepemimpinan dan sifat-sifat ideal pemimpin. Kepala Sekolah lebih ditekankan memiliki model kepemimpinan tradisional (kearifan lokal) yang islami, termasuk sifat kepemimpinan islam yang pluralism. Model kepemimpinan dan sifat-sifat pemimpin itu dipandang lebih selaras dengan kondisi masyarakat Indonesia yang plural dan mayoritas menganut Islam. Pembicaraan tentang kepemimpinan Kepala Sekolah yang ideal menjadi penting ketika dihadapkan pada kenyataan bahwa kepemimpinan pada hampir di semua level Lembaga Pendidkan Agama pada saat ini telah tercoreng dan terdorong terjadinya degradasi dan pergeseran nilai budaya dalam masyarakat (kearifan lokal/ local wisdom). Kepala Sekolah sebagai seorang pemimpin (leader) sudah seharusnya berusaha menjalin hubungan yang baik antara pembantu dan bawahannya (stake holder). Karena tanpa mereka, Pemimpin tidak dapat berbuat apa-apa dalam memberikan pengaruh besar bagi dalam dunia pendidikan. Hal ini dikarenakan lingkungan agamis mempengaruhi proses belajar mengajar untuk siswa di dalam lingkungan belajar yang religius di kepemimpinan sekolah berbasis agama. Kepercayaan menjadi dasar dimana nilai-nilai religius tercipta amanah, ridho, kekuatan jiwa, inspirasi dan cobaan atau ujian. Nilai-nilai religius ini akan menunculkan perilaku religius adanya dakwah dan bekerja. Dampak kemimpinan Kepala Sekolah di Lembaga Pendidikan Agama ini membuktikan adanya nilai tambah (plus value) bagi proses dan Proses Belajar Mengajar (PBM).

\section{DAFTAR RUJUKAN}

Abdussalam, Suroso. 2011. Arah dan Asas Pendidikan Islam. Surabaya: PT. eLBA Fitrah Mandiri Sejahterah.

Afifuddin, dkk. 2009. Metodologi Penelitian Kualitatif. Bandung: CV. Pustaka Setia.

Azra, Azyumardi. 2012. Pendidikan Islam: Tradisi dan Modernisasi di Tengah Tantangan Milenium III. Jakarta: Kencana Preneda Media Goup.

Amini, Ibrahim. 2006. Para Pemimpin Teladan. Jakarta: Al-Huda.

As-Salus, Ali. 1997. Imamah dan Khalifah dalam Tinjauan Syar'i. Jakarta: Gema Insani Press.

Barton, Greg. 2002. Biografi Gus Dur: The Authorized Biography of Abdurrahman Wahid. Yogjakarta: LkiS Printing Cermerlang.

Denzin, Norman K., dkk. 2009. Handbook of Qualitative Research. Yogjakarta: Pustaka Pelajar.

Durkheim, Emile. 2011. The Elementary Forms of The Religius Life. Yogjakarta: IRCiSoD.

Fatimatuzzohrah. 2010. Kepemimpinan Kepala Sekolah dalam mengembangkan kegiatan ekstrakurikuler Pendidikan agama Islam di Sekolah Menengah Atas Muhammadiyah Mataram. Malang: Tesis tidak diterbitkan. Program Pascasarjana Universitas Islam Maulana Malik Ibrahim Malang.

Gistituati, Nurhizrah (Universitas Negeri Padang). Optimalisasi Peran Guru, Murid, Orang Tua dan Masyarakat, serta Pemerintah Daerah Dalam Upaya Peningkatan Kualitas Pendidikan. Skolar Jurnal Kependidikan Volume 6, Nomor 2, Desember 2005. Diterbitkan oleh Program Pascasarjana Universitas Negeri Padang.

Haidar, Ali. 2011. Nahdatul Ulama dan Islam di Indonesia: Pendekatan Fikih dalam Politik. Sidoarjo: Al Maktabah.

Hamdani. 2009. Model Kepemimpinan Kepala Sekolah dalam Pengembangan Lembaga Pendidikan (Studi Kasus di SMP Muhammadiyah 06 Dau Malang). Malang: Tesis tidak diterbitkan. Program Pascasarjana Universitas Muhammadiyah Malang. 
KARANGAN: Jurnal Kependidikan, Pembelajaran, dan Pengembangan, Vol 03 No 02, Bulan September, Tahun 2021 Hal 87-96

Hasanah, Uswatun. 2010. Kepemimpinan Kepala Sekolah dalam Mengembangkan Budaya Agama (Studi Kasus di SMPN 1 Praya Barat Kabupaten Lombok Tengah NTB). Malang: Tesis tidak diterbitkan. Program Pascasarjana Universitas Islam Negeri.

Kartono, Kartini. 1982. Pemimpin dan Kepemimpinan. Jakarta: Rajawali.

Khomeini, Imam. 2002. Sistem Pemerintahan Islam. Jakarta: Pustaka Zahra.

Kuswarno, Engkus. 2009. Metodologi Penelitian Komunikasi Fenomenologi Konsepsi, Pedoman dan Contoh Penelitiannya. Bandung: Widya Padjadjaran.

Koesoema, Doni. 2007. Pendidikan Karakter: Strategi Mendidik Anak di Zaman Gobal. Jakarta: PT. Grasindo.

Lewis, Bernard. 2004. The Crisis of Islam: Antara Perang Suci dan Teror Kotor. Surabaya: Jawa Pos Press.

Maxwell, John C. 2002. 21 Menit Paling Bermakna dalam Hari-hari Pemimpin Sejati. Batam: Interaksara

Nasir, Ridlwan, dkk. 1999. Jejak Kanjeng Sunan: Perjuangan Wali Songo. Surabaya: Yayasan Festival Walisongo kerjasama dengan Penerbit SIC.

Nupail, Akhmad. 2007. Hubungan Motivasi dan Kecerdasan Emosional dengan Kinerja GuruGuru Sekolah Menengah Pertama di Kecamatan Narmada Kabupaten Lombok. Surabaya: Tesis tidak diterbitkan. Program Pascasarjana Universitas Negeri Surabaya.

O’neil, William. 2008. Ideologi-Ideologi Pendidikan. Yogjakarta: Pustaka Pelajar.

Raditya, Ardhie. 2011. Handout Sosiologi Pendidikan. Diterbitkan pada kalangan sendiri.

Raho, Bernard. 2007. Teori Sosiologi Modern. Jakarta: Prestasi Pustaka.

Raihani. 2010. Kepemimpinan Sekolah Transformatif. Yogjakarta: PT. LkiS Printing Cemerlang.

Ritzer, George. 2007. Sosiologi Ilmu Pengetahuan Berparadigma Ganda. Jakarta: PT Raja Grafindo Persada.

Ritzer, George, dkk. 2004. Teori Sosiologi Modern. Jakarta: Kencana.

Rohmat, dan Munjin (Eds). 2010. Kepemimpinan Pendidikan: Konsep dan Aplikasi. Yogjakarta: Litera Buku.

Samani, Muchlas. 2011. "Merenungkan Kembali Arah Pendidikan”. Syah, Sirkuit dan Martadi. Rekontruksi Pendidikan: Kumpulan Pemikiran Tentang Perlunya Merekontruksi Pendidikan di Indonesia. Surabaya: UNESA University Press

Sapriya. 2009. Pendidikan IPS. Bandung: PT Remaja Rosdakarya.

Sugiyono. 2009. Memahami Penelitian Kualitatif. Bandung: CV Alfabeta.

Soeprapto, Gerdjito. 2010. Pembelajaran IPS Terpadu Studi Kasus SMP Negeri Kabupaten Pati. Surakarta: Tesis tidak diterbitkan. Program Pascasarjana Universitas Sebelas Maret Surakarta.

Soyomukti, Nurani. 2010. Teori-Teori Pendidikan: Tradisional, (Neo) Liberal, Marxis-Sosialis, Postmodern. Yogjakarta: Ar-Ruzz Media Group

Sukowibowo, Parsum. 2006. Hubungan Sekolah Dengan Masyarakat (Studi Kasus di SMA Darul Ulum 2 Unggulan Badan Pengkajian dan Penerapan Teknologi Jombang). Surabaya: Tesis tidak diterbitkan. Program Pascasarjana Universitas Negeri Surabaya.

Suryarman. 2010. Analisis Kepemimpinan Multikultural di Sekolah Menengah dalam Upaya Mencegah Fenomena Gegar Budaya: Konteks Indonesia. Sosiohumanika: 3 (2) 2010.

Rohmad, Ali. 2004. Kinerja Guru Bidang Studi IPS Sekolah Menegah Pertama di Kota Kediri. Surabaya: Tesis tidak diterbitkan. Program Pascasarjana Universitas Negeri Surabaya.

Warsono. 2011. "Memahami Hakikat Kemanusiaan dan Pendidikan". Syah, Sirkuit dan Martadi. Rekontruksi Pendidikan: Kumpulan Pemikiran Tentang Perlunya Merekontruksi Pendidikan di Indonesia. Surabaya: UNESA University Press.

Weber, Max. 2000. Etika Prostestan dan Semangat Kapitalisme. Surabaya: PT. Pustaka Prometeha.

Yin, Robert K. 2003. Studi Kasus (Desain dan Metode). Jakarta: PT. Raja Grafindo Persada.

Zuhairy, Tsanin. Dunia Keseharian Sebagai Lokus Kesadaran Intersubjektif. Diskursus tentang Sosiologi Interpretatif dalam Terang. Online: www.tsanincenter.blogspot.com. Di akses pada tanggal 3 Januari 2011. 